\title{
Effectiveness of internal audit in local governments: The moderating role of internal and external auditors' relations
}

\section{Dwi Ratmono $^{\mathrm{a}^{*}}$ and Darsono Darsono ${ }^{\mathrm{a}}$}

\begin{tabular}{l}
${ }^{a}$ Universitas Diponegoro, Indonesia \\
\hline C H R O N I C L E \\
\hline Article history: \\
Received June 18, 2021 \\
Received in revised format June \\
282021 \\
Accepted July 22021 \\
Available online \\
July 5 2021 \\
\hline Keywords: \\
Internal audit \\
Independence \\
Competence \\
Management support \\
Cooperative relationships
\end{tabular}

\section{Introduction}

The role of internal audit in public service organizations is to provide facilities for independent assessment and review, to determine and report the level of control reliability (Coupland, 1993; Arena et al., 2006). The role of internal audit has traditionally only emphasized internal control and compliance with financial management. However, internal audit has evolved significantly in recent years towards a broader internal consulting role within the corporate risk management function. Therefore, it is important to investigate how effectively internal audit functions as originally intended (Alzeban \& Gwilliam, 2014; Davidson, 1991). The effectiveness of internal public sector audits in Indonesia is a necessity in line with the increasing demands of the public for good and clean governance. In addition, regional financial management in various local governments in Indonesia has not been fully implemented according to regulations. In the Summary of Audit Report for semester I of 2020 issued by the Audit Board of the Republic of Indonesia, there are still various irregularities in regional financial management indicating criminal acts and causing losses. The formulation of the research problem can be described as follows. Several previous studies have examined the factors that influence the effectiveness of government internal audit. Some of the variables analyzed include auditor competence, the relationship between internal and external auditors, management support for internal audit and the independence of internal audit. However, the results of these studies show

* Corresponding author

E-mail address: dwi.ratmono2@gmail.com (D. Ratmono)

C 2022 Growing Science Ltd. All rights reserved.

doi: 10.5267/j.ac.2021.7.004 
inconsistent findings about the determinants of internal audit effectiveness in government organizations (Alzeban \& Gwilliam, 2014; Shamsuddin, 2014; Chidinma et al., 2016; Udeh \& Nwadialor, 2016; Kagaba \& Mulyungi, 2016; Mupeta, 2017; Montondon \& Fischer, 1999; Ofori \& Lu, 2018; Saputra et al., 2020; Ratnawati, 2020). The inconsistency of the findings that test the determinants of the effectiveness of internal audit in government organizations indicates the need for further research by developing models.

Hair et al. (2017) stated that if the influence of the independent variable on the dependent variable varies in various situations, it may be caused by the presence of a moderating variable. Based on the explanation of Hair et al. (2017), this study develops a model for determining the effectiveness of internal audit in government organizations by adding a moderating variable. The relevance of this research isas follows. The results of this study can make a contribution related to auditing, as well as provide evidence and analysis of factors affecting the effectiveness of internal audit. For local governments, this research can provide an understanding of the factors affecting the effectiveness of internal audit and is expected to become a reference in implementing an effective internal audit. For the Audit Board as a government external auditor, this study can provide information about the relationship between internal and external auditors in achieving an effective internal audit.

\section{Literature Review}

In the Indonesian Government Internal Audit Standards, internal audit is defined as an independent and objective activity in the form of assurance and consulting activities, which is designed to add value and improve the operations of an organization. This activity helps the organization (auditee) achieve its objectives by using a systematic and orderly approach to assess and improve the effectiveness of risk management, control, and governance processes.

Relationship agency can be defined as a contract between the owner of the organization and the top management of the company. Managers work in the organization as agents to perform services on behalf of owners who delegate decisionmaking authority to managers. Authority it can be misused by managers to serve their own personal interests. Therefore, the existence of an audit committee, external and internal auditors, will assist organizations in improving their performance and will also ensure that management implements plans according to procedures (Adams, 1994).

Internal auditors are often employed by senior management but at the same time, they are also agents of the board of directors and audit committees who believe in the ability of internal auditors to evaluate the performance of senior management. Internal auditors must carry out the audit process at a professional level demanding the professional education and certification, experience, and other competencies needed to carry out their responsibilities flawlessly. Internal auditors with these requirements and the existence of a training program for internal auditors will increase the level of confidence of the board and audit committee in the competence of internal auditors (Endaya \& Hanefah, 2013)

Worldwide professional guidelines and standards, referring to the Institute of Internal Auditor, demonstrate that proper independence and objectivity can be obtained by reporting up to the organizational level that provides the internal audit department to carry out its responsibilities free from disruption; avoid conflicts of interest; has direct contact with the board and senior management; have unrestricted access to records, employees and departments; have the appointment and dismissal of internal auditing chiefs not under the direct control of executive management; and do not perform non-audit work.

Previous research has shown that a lack of independence is a barrier to satisfactory internal audit performance in developing countries. In South Africa, Schyf (2000) saw the lack of independence of internal audit as a problem facing the internal audit function in the country. In particular, he identified concerns about the form of communication and the level of reporting and the implications for independence. Another study in developing countries highlighted that the lack of independence of the audit function has reduced effectiveness of internal audit (Brierley et al., 2003; Ofori \& Lu, 2018). In contrast, the study of Chidinma et al. (2016), Kagaba and Mulyungi (2016), Mupeta (2017) and Saputra et al. (2020) show empirical evidence that adequate independence can increase the effectiveness of internal auditors.

\section{$\mathbf{H}_{1}$ : Independence has a positive influence on the effectiveness of internal audit.}

Auditor competence is a key element in the effectiveness of internal audit (IIA, 2006). The Indonesian Government Internal Audit Standard (SAIPI) number 2010 on auditor competence states that internal audit assignments must be carried out with professional competence and accuracy. Auditors must have the education, knowledge, expertise and skills, experience, and other competencies needed to carry out their responsibilities.

Several studies in the public sector on the effect of auditor competence on the effectiveness of internal audit have been conducted. The results of previous studies show weak competence as one of the factors that reduces the effectiveness of internal audit (Brierley et al., 2001, 2003: Gwilliam \& El-Nafabi, 2002; Mihret \& Yismaw, 2007; Mupeta, 2017; Shamsuddin, 2018; Ofori \& Lu, 2018). Conversely, adequate auditor competence can increase the effectiveness of internal auditors in government (Udeh \& Nwadialor, 2016; Saputra et al., 2020; Ratnawati, 2020)

\section{H2: Internal auditor competence has a positive influence on the effectiveness of internal audit.}


With the support of top management, internal auditors can obtain sufficient resources to carry out their duties and responsibilities and the internal audit department can employ qualified staff and provide continuous training for development (Alzeban \& Sawan, 2013; Cohen \& Me, 2010 ). International Standards for the Professional Practice of Internal Auditing (ISPPIA) highlighted the importance of the relationship between internal audit and senior management and how management can support internal audit. Senior management must be involved in the internal audit plan.

Previous research states that support from top management is an important factor for the success of the internal audit function. Others found that management support is one of the determining factors in the effectiveness of internal audit in the Malaysian public sector, after the adequacy of audit staff. They stated that with management support, internal audit recommendations are likely to be implemented and internal audit resources will be good in terms of staff numbers and budget. Van Gansberghe (2005) shows that to achieve effectiveness, internal audit requires management support and appreciation of the contribution that internal audit can add to organizational value. Other research results that show adequate management support can increase the effectiveness of internal audit, including Kagaba and Mulyungi (2016), Mupeta (2017), Arena and Azzone (2007, 2009) and Saputra et al. (2020).

\section{$\mathbf{H}_{3}$ : Management support has a positive influence on the effectiveness of internal audit.}

Coordination and cooperation between internal and external auditors play an important role that benefits the organization and external stakeholders. Examples of such coordination and cooperation include joint planning, exchange of information, opinions and reports to facilitate high-quality audits and prevent unnecessary duplication of work. The Indonesian Government Internal Audit Standard states that the objective of coordination with external auditors is to ensure proper coverage and minimize repetition of activities.

Coordination is carried out by submitting the annual internal audit activity plan as well as the results of the internal audit activities that have been carried out by APIP during the period that will be examined by external auditors and / or other auditors. By presenting the results of the internal audit activities, the external auditors and / or other auditors are expected to use these results to reduce the scope of their assignments.

Previous research has shown that the right collaborative relationship between internal and external auditors will increase the efficiency and effectiveness of audits and help management provide quality public services (Shamsuddin, 2018). The absence of cooperation between internal and external auditors was identified as a factor affecting the quality of public sector audits in developing countries (Brierley et al., 2001; Gwilliam \& El-Nafabi, 2002; Sterck \& Bouckaert, 2006). Al-Garni (2008) found that a lack of cooperation between external and internal auditors can weaken the influence of competence, independence, and management support on the effectiveness of internal audit. Good cooperation between internal and external auditors is expected to strengthen the positive influences of these three factors on internal audit.

\section{H4: The cooperative relationship between internal and external auditors strengthens the positive influence of independence on the effectiveness of internal audit. \\ Hs: The cooperative relationship between internal and external auditors strengthens the positive influence of competence on the effectiveness of internal audit. \\ $\mathbf{H}_{6}$ : The cooperative relationship between internal and external auditors strengthens the positive influence of management support on the effectiveness of internal audit.}

\section{Research Methods}

The internal audit effectiveness variable is measured by providing a score on aspects of the internal audit function consisting of the ability to plan, develop organizational productivity, assess the consistency of results with predetermined goals and objectives, implementation of internal audit recommendations, evaluation and improvement of risk management, evaluation of the internal control system, and recommendations for improvement.

The competency variable of internal audit staff is measured by providing a score on the attributes of internal audit staff, namely work experience in the field of internal audit, continuous development (annual average training hours).

The variable of internal audit independence is measured by providing a score on the attributes of internal audit independence, namely the level of independence, level of reporting, direct contact with the board and senior management, conflicts of interest, interference, unlimited access to all departments and employees, appointment and dismissal of the head of internal audit, and performance on non-audit activities. Management support variable for internal audit is measured by providing a score for the attributes of management support for internal audit, namely supporting internal audit to carry out its duties and responsibilities, involvement in internal audit planning, reports on internal auditor team work sent to management, management responses to audit reports. internal, and the resources of the internal audit department. The variable of cooperation between internal auditors and external auditors is measured by providing a score on the attributes of the relationship between internal auditors and external auditors, namely attitudes towards external auditors, coordination (including discussing common interests), discussion of audit plans, the level of confidence of external auditors in internal 
audit work, meeting frequency, sharing working papers, and promotion management on the relationship between the two organizations.

Respondents were asked to provide an assessment using a five-point Likert scale, namely between "strongly disagree" to "strongly agree".

The population in this study were auditors at the inspectorate at 8 local governments, namely Sleman, Bantul, Kulon Progo, Yogyakarta City and DI Yogyakarta Province as well as the Inspectorate of Semarang City, Semarang Regency and Central Java Province. The primary data were obtained through a questionnaire distributed to the internal auditors.

The data analysis approach used in this research was Structural Equation Modeling (SEM) based on components or variants, better known as the approach Partial Least Square (PLS). To perform this analysis, the software used was WarpPLS 7.0.

PLS is an alternative to covariance-based SEM whose analysis orientation shifts to component best predictive model. The PLS algorithm aims to obtain the best weight estimate for each indicator block of each latent variable. Furthermore, PLS is an analysis that is not based on many assumptions and is more flexible, such as a normal distribution, can be used for various scales and a small sample of research. In addition, PLS can analyze models with formative and reflective indicators simultaneously (Hair et al., 2017).

\section{Findings}

The research data used in this study is primary data obtained by using a questionnaire that has been distributed to the auditors of the inspectorate at 8 local governments. Until the deadline for returning the questionnaire, from 187 questionnaires distributed, 137 questionnaires have been returned. The return rate is $73.26 \%$ and the remaining $26.47 \%$ is not returned. The profile of the respondents in this study is mostly female auditors and has an undergraduate education level. Apart from that, the working experience and training that were followed were in the adequate category.

Descriptive statistics were carried out to analyze data based on respondents' answers to each of the indicators of the research variables. Table 6 below shows the descriptive statistics of respondents' answers.

Table 1

Descriptive statistics

\begin{tabular}{|c|c|c|c|c|c|c|}
\hline \multirow{2}{*}{ Variables } & \multirow{2}{*}{$\mathbf{N}$} & \multicolumn{2}{|c|}{ Theoretical } & \multicolumn{2}{|c|}{ Actual } & \multirow{2}{*}{ Std. Dev. } \\
\hline & & Range & Mean & Range & Mean & \\
\hline Auditor Cooperation & 137 & $10-50$ & 30.00 & $17-50$ & 34.04 & 5.45 \\
\hline Management Support & 137 & $6-30$ & 18.00 & $16-30$ & 23.58 & 3.51 \\
\hline Independency & 137 & $6-30$ & 18.00 & $14-30$ & 19.58 & 3.12 \\
\hline Effectiveness & 137 & $11-55$ & 33.00 & $33-55$ & 45.72 & 5,94 \\
\hline Competence & 137 & $2-10$ & 6.00 & $2-10$ & 7.15 & 1.98 \\
\hline
\end{tabular}

Based on Table 1, the auditor cooperation variable has a theoretical range between 10 and 50 with an average value of 30 . In the actual range, the auditor relationship variable has a range of 17 to 50 with a mean value of 34.04 and a standard deviation of 5.45. The average value of the answers to these variables in the real range is above the average value of the theoretical range. This analysis indicates that the respondent's perception of the auditor relationship variable is at a strong level. The management support variable has a theoretical range between 6 and 30 with a mean value of 18 . In the actual range, the management support variable has a range of 16 to 30 with a mean value of 23.58 and a standard deviation of 3.51. This analysis indicates that the respondent's perception of the management support variable is at a strong level. The management support variable has a theoretical range between 6 and 30 with a mean value of 18. In the actual range, the independence variable has a range of 14 to 30 with a mean value of 19.58 and a standard deviation of 3.12 . This analysis indicates that the respondent's perception of the auditor relationship variable is at a strong level.

The internal audit effectiveness variable has a theoretical range between 11 and 55 with an average value of 33. In the actual range, the variable of internal audit effectiveness has a range of 33 to 55 with an average value of 45.72 and a standard deviation of 5.94. This analysis indicates that the respondents' perceptions of the internal audit effectiveness variable are at a strong level. The internal auditor competency variable has a theoretical range between 2 and 10 with an average value of 6 . In the actual range, the internal auditor competency variable) has a range of 2 to 10 with an average value of 7.15 and a standard deviation of 1.98. The average value of the answers to these variables in the real range is above the average value of the theoretical range. This analysis indicates that the respondent's perception of the internal auditor competency variable is at an adequate level.

The PLS method has two stages of model evaluation, namely the evaluation of the measurement model or outer model and evaluation of structural models or inner model. Evaluation of the measurement model is carried out based on criteria of 
convergent validity, discriminant validity, and composite reliability, meanwhile and evaluation of the structural model is carried out based on the path coefficient criteria and its significance ( $t$ test) and the value of $\mathrm{R}^{2}$ (Hair et al., 2017).

Convergent validity in measurement models with reflective indicators were assessed based on the correlation between the indicator scores with the construct score (outer loadings). Individual indicators can be said to be valid if it has a correlation value of more than 0.70 . However, the correlation value between 0.40 to 0.70 can be accepted with significant conditions with a $\mathrm{p}$ value of less than 0.05 (Hair et al., 2017). The following table 2 shows the values loading factor of each of the reflective construct indicators.

Table 2

Convergent Validity of Reflective Latent Variables

\begin{tabular}{|c|c|c|c|c|c|c|}
\hline & Independence & Relationship & Support & Effectiveness & Type & $\mathrm{P}$ value \\
\hline ind1 & 0.869 & -0.217 & 0.112 & 0.116 & Reflect & $<0.001$ \\
\hline ind 2 & 0.869 & 0.217 & -0.112 & -0.116 & Reflect & $<0.001$ \\
\hline rell & -0.207 & 0.767 & -0.081 & 0.242 & Reflect & $<0.001$ \\
\hline rel2 & -0.056 & 0.745 & 0.247 & -0.119 & Reflect & $<0.001$ \\
\hline rel3 & 0.245 & 0.715 & -0.002 & -0.219 & Reflect & $<0.001$ \\
\hline rel4 & 0.030 & 0.746 & -0.277 & 0.038 & Reflect & $<0.001$ \\
\hline rel5 & 0.004 & 0.729 & 0.118 & 0.043 & Reflect & $<0.001$ \\
\hline supp1 & -0.130 & 0.090 & 0.710 & 0.201 & Reflect & $<0.001$ \\
\hline supp2 & 0.010 & -0.018 & 0.627 & 0.357 & Reflect & $<0.001$ \\
\hline supp3 & 0.006 & -0.074 & 0.789 & 0.001 & Reflect & $<0.001$ \\
\hline supp4 & -0.082 & -0.115 & 0.766 & -0.065 & Reflect & $<0.001$ \\
\hline supp5 & 0.196 & 0.127 & 0.736 & -0.428 & Reflect & $<0.001$ \\
\hline effect1 & 0.184 & -0.179 & -0.094 & 0.739 & Reflect & $<0.001$ \\
\hline effect 2 & 0.229 & -0.031 & -0.163 & 0.722 & Reflect & $<0.001$ \\
\hline effect 3 & 0.062 & 0.241 & -0.086 & 0.604 & Reflect & $<0.001$ \\
\hline effect 4 & 0.076 & 0.070 & 0.069 & 0.827 & Reflect & $<0.001$ \\
\hline effect5 & 0.228 & 0.007 & 0.066 & 0.811 & Reflect & $<0.001$ \\
\hline effect6 & 0.044 & 0.152 & 0.020 & 0.833 & Reflect & $<0.001$ \\
\hline effect 7 & -0.160 & -0.107 & 0.101 & 0.836 & Reflect & $<0.001$ \\
\hline effect8 & -0.156 & -0.069 & 0.157 & 0.836 & Reflect & $<0.001$ \\
\hline effect 9 & -0.324 & 0.053 & -0.129 & 0.807 & Reflect & $<0.001$ \\
\hline effect1 & -0.077 & -0.009 & -0.037 & 0.814 & Reflect & $<0.001$ \\
\hline effect1 & -0.046 & -0.091 & 0.040 & 0.770 & Reflect & $<0.001$ \\
\hline
\end{tabular}

There are 4 latent variables that are measured reflectively, namely independence, the relationship of cooperation between internal auditors and external auditors, management support and the effectiveness of the internal audit function. As presented in Table 7, all of these latent variables have met the criteria for convergent validity, indicated by the loading value of the indicators above 0.60 (above the minimum 0.40) and significant at alpha 0.001 .

Meanwhile, the convergent validity of latent variables which is measured formatively is evaluated with the weight indicator (Hair et al., 2017). The conditions that must be met are the indicators of formative latent variables that must be significant and there is no multicollinearity.

Table 3

Convergent Validity of Formative Latent Variables

\begin{tabular}{llllll}
\hline & Compete & Type & SE & P value & VIF \\
\hline comp1 & 0.646 & Formative & 0.074 & $<0.001$ & $<01$ \\
comp2 & 0.646 & Formative & 0.074 & 1.041 \\
\hline
\end{tabular}

Table 3 shows that the indicator weight for the competency indicators is 0.646 respectively and is significant with a $p$ value $<0.001$. In addition, there is no multicollinearity indicated by a VIF value of 1.041 below the maximum limit of 5 (Hair et al., 2017). Thus, the criteria for convergent validity have been met. Discriminant validity was analyzed by Fornell-Larcker criterion and Heterotrait-Monotrait ratio (Hair et al., 2017). Table 9 presents the results of the Fornell-Larcker criterion, namely the root of the Average Variance Extracted (AVE) in the diagonal column and the correlation between latent variables in the same column. The discriminant validity is fulfilled if the AVE root in the diagonal column is higher than the other numbers in the same column. The results in table 4 show that the criteria for discriminant validity have been met.

Table 4

Discriminant Validity: Fornell-Larcker Criterion

\begin{tabular}{|c|c|c|c|c|c|}
\hline Variables & Independence & Competence & Relationship & Support & Effectiveness \\
\hline Independence & 0.869 & -0.159 & -0.034 & 0.043 & 0.198 \\
\hline Competence & -0.159 & 0.774 & 0.156 & 0.265 & 0.287 \\
\hline Relationship & -0.034 & 0.156 & 0.741 & 0.598 & 0.442 \\
\hline Support & 0.043 & 0.265 & 0.598 & 0.728 & 0.639 \\
\hline Effectiveness & 0.198 & 0.287 & 0.442 & 0.639 & 0.785 \\
\hline
\end{tabular}

Note: Square roots of average variances extracted (AVEs) shown on diagonal. 
Apart from the Fornell-Larcker criterion, the discriminant validity was also evaluated by the HTMT ratio, the results of which are presented in Table 5. Discriminant validity is fulfilled indicated by the total HTMT ratio below the maximum limit of 0.85 (Hair et al., 2017).

Table 5

Discriminant Validity: HTMT Ratio

\begin{tabular}{llll}
\multicolumn{1}{c}{ Variables } & Independence & Competence & Relationship \\
\hline Competence & 0.335 & & \\
Relationship & 0.162 & 0.304 & 0.766 \\
Support & 0.099 & 0.529 & 0.512 \\
Effectiveness & 0.270 & 0.508 & 0.756 \\
\hline HTMT ratios $($ good if $<\mathbf{0 . 9 0}$ best if $<\mathbf{0 . 8 5})$ & &
\end{tabular}

In addition to evaluating convergent and discriminant validity, construct reliability is also evaluated by composite reliability and Cronbach alpha. The results in table 6 show that the reliability of the construct has been fulfilled, indicated by the composite reliability and Cronbach alpha values above 0.70 (Hair et al., 2017). In addition, AVE has met the criteria above 0.50 . In the SEM-PLS analysis, it is also necessary to ensure that the model is free from the problem of full collinearity (Hair et al., 2017). The results in table 11 show that there is no full collinearity problem indicated by the full collinearity VIF value below 3.3. Overall, the evaluation of the measurement model has met the requirements so that the analysis can be continued on the structural model for hypothesis testing.

Table 6

Composite Reliability and Full Collinearity

\begin{tabular}{|c|c|c|c|c|c|}
\hline Criteria & Independence & Competence & Relationship & Support & Effectiveness \\
\hline Composite Reliability & 0.860 & 0.750 & 0.859 & 0.848 & 0.946 \\
\hline Cronbach's Alpha & 0.675 & 0.333 & 0.794 & 0.776 & 0.936 \\
\hline AVE & 0.754 & 0.600 & 0.549 & 0.529 & 0.615 \\
\hline Full Collinearity VIF & 1.241 & 1.219 & 1.908 & 2.228 & 1.979 \\
\hline
\end{tabular}

The evaluation of the structural model aims to test the hypothesis by analyzing the path coefficients between latent variables and their significance. Before analyzing the results of the path coefficient test, an evaluation of the fit model was carried out with the index provided by the output of the WarpPLS 7.0 software (Kock, 2020). Based on the results of the structural model, the results of hypothesis testing can be summarized as presented in table 7.

Table 7

Hypothesis Testing Results

\begin{tabular}{|c|c|c|c|}
\hline Path & Coefficient & p-value & Effect Size \\
\hline Independence $\rightarrow$ Effectiveness & 0.363 & $<0.001$ & 0.140 \\
\hline Competence $\rightarrow$ Effectiveness & 0.175 & 0.018 & 0.052 \\
\hline Support $\rightarrow$ Effectiveness & 0.538 & $<0.001$ & 0.352 \\
\hline Independence $*$ Relationship $\rightarrow$ Effectiveness & 0.165 & 0.023 & 0.047 \\
\hline Competence $*$ Relationship $\rightarrow$ Effectiveness & -0.083 & 0.162 & 0.018 \\
\hline Support * Relationship $\rightarrow$ Effectiveness & 0.085 & 0.155 & 0.025 \\
\hline R-squared & & 0.541 & \\
\hline Q-squared & & 0.543 & \\
\hline
\end{tabular}

Hypothesis 1 states that independence has a positive influence on the effectiveness of the internal audit function. The results in table 13 show the path coefficient of 0.363 and it is significant with a p value of less than 0.001 . Thus hypothesis 1 is supported by empirical evidence of this study. Hypothesis 2 states that competence has a positive influence on the effectiveness of the internal audit function. The results in table 13 show the path coefficient of 0.175 and it is significant with a $\mathrm{p}$ value of less than 0.05 . Thus hypothesis 2 is supported by empirical evidence of this study. Hypothesis 3 states that management support has a positive influence on the effectiveness of the internal audit function. The results in table 13 show the path coefficient of 0.538 and it is significant with a $p$ value of less than 0.001 . Thus hypothesis 3 is supported by empirical evidence of this study.

Furthermore, the results of hypothesis testing are analyzed regarding the role of the cooperation between internal and external auditors in strengthening the influence of these three factors on the effectiveness of the internal audit function.

Hypothesis 4 states that the cooperative relationship between internal and external auditors strengthens the independent positive influence on internal audit effectiveness. The test results show that the coefficient of the independence and relationship interaction is 0.165 and is significant with a $p$ value of less than 0.05 . These results show that hypothesis 4 is supported.

Hypothesis 5 states that the cooperative relationship between internal and external auditors strengthens competence and positive influence on the effectiveness of internal audit. The test results show the coefficient of interaction between 
competence and cooperation (competence* relationship) of -0.083 and not significant with a palue of more than 0.05 . These results indicate hypothesis 5 is not supported.

Hypothesis 6 states that cooperative relationships between internal and external auditors strengthens the positive influence of management support on the effectiveness of internal audit. The test results show the interaction coefficient of management support and cooperation (support * relationship) of 0.085 and not significant with a $p$ value of more than 0.05 . These results indicate hypothesis 6 is not supported.

Evaluation of the structural model is also carried out by analyzing the coefficient of determination R-Squared. The coefficient of determination ( $R$-squared) 0.75 ; 0.50 ; and 0.25 for each endogenous latent variable in the structural model can be interpreted as substantial, moderate, and weak (Hair et al., 2017). The R-Squared value in table 13 is 0.541 which is included in the moderate category. This also means that the variance of the exogenous variables in this research model can explain the endogenous latent variables by $54.1 \%$. The Q-squared value is an indicator predictive relevance (Hair et al., 2017). Score $Q$-squared that is greater than zero indicates that the exogenous latent variable has predictive relevance to the affected endogenous latent variable. The results in table 13 show a Q-squared value of 0.543 which indicates that the exogenous latent variables in this research model have predictive relevance in explaining the practice of internal audit effectiveness. Effect size is calculated as the absolute value of each predictor's latent variable on the value $R$ squared criterion variable. Effect size can be grouped into 3 categories, namely weak (0.02), medium (0.15), and large (0.35). Based on the results in table 13, the predictor exogenous latent variable that had a major contribution was management support, while independence was in the moderate category.

\section{Discussions and Implications}

The results of hypothesis testing show that there is a positive influence on the independence of internal audit on the effectiveness of internal audit. This indicates that the greater the independence of internal audit, the greater the effectiveness of internal audit. The great independence of internal audit can be seen from indicators that include the level of independence, conflicts of interest, direct contact with senior management, unlimited access to all departments and employees, the appointment and dismissal of the head of internal audit, and performance on non-audit activities. When these indicators show a high level, the internal audit function will be more effective. This can be seen from the research descriptive statistics which show that the average value of the answers to the management support variable is above the theoretical average value, and then the average value of the answers to the internal audit effectiveness variable is also above the average value of the theoretical range.

These results support the research conducted by Alzeban and Gwiliam (2014), Chidinma et al. (2016), Kagaba and Mulyungi (2016), Mupeta (2017) and Saputra et al. (2020) show empirical evidence that adequate independence can increase the effectiveness of internal auditors. The results of this hypothesis testing also show that to increase the effectiveness of internal audit, internal auditors must uphold an attitude of independence, objectivity and freedom from conflicts of interest in carrying out their professional responsibilities. In addition, the inspectorate as an organization that carries out audit tasks is responsible for ensuring that independence and objectivity are maintained in all stages of the examination.

The results of hypothesis testing indicate that there is a positive influence of the competence of internal auditors on the effectiveness of internal audit. This indicates that the higher the level of auditor competence will increase the effectiveness of internal audit. The level of competence of the internal auditors can be seen from the indicators which include work experience and the number of hours of audit training. When these indicators show a high level, the internal audit function will be more effective. This can be seen from the research descriptive statistics which show that the average value of the answers to the management support variable is above the theoretical average value, and then the average value of the answers to the internal audit effectiveness variable is also above the average value of the theoretical range.

These results support research conducted by Alzeban and Gwiliam (2014). Udeh and Nwadialor (2016), Saputra et al. (2020), Al-Twaijry et al. (2003) and Ratnawati (2020) which state that the competence of internal auditors has a significant influence on the effectiveness of public sector internal audits. The results of this hypothesis testing also show that to increase the effectiveness of public sector internal audit, the regional head as the highest leader in the organization must increase the competence of internal auditors by increasing the number of education and training so that internal auditors have the ability and professional skills to carry out their duties and responsibilities.

The third hypothesis testing shows the result which states that there is a positive influence of management support on the effectiveness of internal audit. This indicates that the greater management support for internal audit the higher the effectiveness of internal audit. Great management support for internal audit can be seen from indicators that include management support for internal auditors in carrying out their duties and responsibilities, involvement in internal audit planning, management response to internal audit reports, and resources from the internal audit department. When these indicators show a high level, the internal audit function will be more effective. This can be seen from the research descriptive statistics which show that the average value of the answers to the management support variable is above the theoretical average value, and then the average value of the answers to the internal audit effectiveness variable is also above the average value of the theoretical range. 
These results support research conducted by Mihret and Yismaw (2007), Alzeban and Gwiliam (2014), Kagaba and Mulyungi (2016), Mupeta (2017) and Saputra et al. (2020) which states that management support for internal audit has a positive influence on the effectiveness of internal audit in government organizations. This empirical evidence also shows that to increase the effectiveness of public sector internal audit, the regional head as the highest leader in the organization must increase support for the internal audit function which is manifested in the involvement of regional heads in internal audit planning, availability of sufficient budget in carrying out duties and the internal audit function, and regional heads' responses to internal audit report.

The results of testing the moderation hypothesis indicate that the cooperative relationship between internal and external auditors can strengthen the positive influence of independence on the effectiveness of internal audit. Meanwhile, the influence of the two other variables, namely competence and management support on effectiveness, is not moderated by the cooperative relationship between internal and external auditors. The level of the internal auditor relationship can be seen from indicators that include attitudes towards external auditors, coordination, discussion of the audit plan, the level of confidence of the external auditors in internal audit work, meeting frequency, sharing of working papers, and management promotion of the relationship between the two organizations. Descriptive statistics show that there are respondents' answers leading to a low level of discussion indicators between internal and external auditors related to audit activities, communication between internal and external auditors in every audit conducted by external auditors, and activities to share working papers between internal and external auditors. This can be seen from the descriptive statistics showing that the actual range value of the auditor relationship variable is 17 to 50 with an average value of 34.04 and the theoretical range value is between 10 to 50 with an average value of 30 with a standard deviation of 5.45 . This is probably the reason that hypotheses 5 and 6 are not supported.

\section{Conclusion}

This research is based on the main idea that to improve the effectiveness of internal audit, competency, independence, management support, and cooperation with external auditors are required. The results showed that greater internal audit independence has a positive influence on the effectiveness of internal audit. This supports the statement in the auditing standards of state finances which states that the auditing and examining organizations are responsible for maintaining their independence in such a way so that opinions, conclusions, considerations or recommendations resulting from the results of the investigation carried out are impartial and are seen as impartial by any party.

The results showed that the competence of internal auditors has a positive influence on the effectiveness of internal audit. This supports the agency theory which states that internal auditors as agents must carry out the audit process at a professional level that demands the professional education and certification, experience, and other competencies needed to adequately carry out their responsibilities. Greater management support for internal audit has a positive influence on the effectiveness of internal audit. Meanwhile, the test results show that the cooperative relationship does not strengthen the influence of competence and management support on the effectiveness of the internal audit function. These results indicate that the relationship between cooperation is still limited to increasing aspects of independence while formal aspects such as knowledge transfer and management support still need to be improved. The novelty of this study is to add a moderating variable, namely the cooperation of internal and external auditors into the research model.

\section{References}

Adams, M. B. (1994). Agency Theory and the Internal Audit. Managerial Auditing Journal, 9(8), 8-12.

Al-Garni, A. (2008). Government auditing in Saudi Arabia: Auditors' opinion in the General Audit Bureau. Institute of Public Administration, 48(1), 39-79.

Al-Twaijry, A.., Brierley, J. \& Gwilliam, D. (2003). The Development of Internal Audit in Saudi Arabia: An Institutional Theory Perspective. Critical Perspectives on Accounting, 14(5), 507-531.

Alzeban, A. \& Gwilliam, D. (2014). Factor affecting the internal audit effectiveness: A survey of the Saudi public sector. Journal of International Accounting, Auditing and Taxation, 23, 74-86

Alzeban, A.\& Sawan, N. (2013). The role of internal audit function in the public sector context in Saudi Arabia. African Journal of Business Management, 7(6), 443-454.

Arena, M., Arnaboldi, M. \& Azzone, G. (2006). Internal Audit in Italian Organizations: A Multiple Case Study. Managerial Auditing Journal, 21(3), 275-292.

Arena, M. \& Azzone, G. (2007). Internal Audit Departments: Adoption and Characteristics in Italian Companies. International Journal of Auditing, 11(2), 91-114.

Arena, M., \& Azzone, G. (2009). Identifying organizational drivers of internal audit effectiveness. International Journal of Auditing, 13, 43-60.

Brierley, J., El-Nafabi, H., \& Gwilliam, D. (2001). The problems of establishing internal audit in the Sudanese public sector. International of Journal Auditing, 5(1), 73-87.

Brierley, J., El-Nafabi, H., \& Gwilliam, D. (2003). An examination of internal audit in the Sudanese public sector. Research in Accounting in Emerging Economies, 5, 177-195. 
Chidinma, O, Nwadialor O \& Ifureza, S. (2016). Effective internal audit as a tool for improving institutional governance and accountability in the public sector. Advances in Applied Science Research, 7(4), 1-10.

Cohen, A., \& Sayag, G. (2010). The effectiveness of internal auditing: An empirical examination of its determinants in Israeli organizations. Australian Accounting Review, 20(3), 296-307.

Davidson, P. (1991). The Great Communicators. The Internal Auditor, 48(6), 26-31.

Dittenhofer, M. (2001). Internal audit effectiveness: An expansion of present methods. Managerial Auditing Journal, 16 (8), 443-450

Endaya \& Hanefah, (2013). Internal Audit Effectiveness: An Approach Proposition to Develop the Theoretical Framework. Research Journal of Finance and Accounting, 4(10), 2013

Gwilliam, D., \& El-Nafabi, H. (2002). The possibility of transition to public sector modern auditing techniques and procedures found in developing countries; the case of Sudan. Accounting Research, The Saudi Accounting Association, 6(2), 161-196.

Halimah, N., R. Othman, \& M. Jusoff. (2009). Journal of Modern Accounting and Auditing, 5(9), 53-62.

Institute of Internal Auditors (IIA). 2006. The role of auditing in public sector governance. Florida: IIA.

Kagaba, J \& P. Mulyungi. (2018). Determinants of Internal Audit Effectiveness of Public Sector; A Case Study Rwanda Revenue Authority. International Journal of Science and Research (IJSR), 7(11), 617-620.

Komite Standar Audit AAIPI. (2013). Standar Audit Intern Pemerintah Indonesia.

Mihret, D., \& Yismaw, A. (2007). Internal audit effectiveness: An Ethiopian public sector case study. Managerial Auditing Journal, 22(5), 470-484.

Mihret, D., James, K. \& Mula, J. M. (2010). Antecedents and Organisational Performance Implications of Internal Audit Effectiveness: Some Propositions and Research Agenda. Pacific Accounting Review, 22(3), 224-252.

Montondon, L. G., \& Fischer, M. (1999). University audit departments in the United States. Financial Accountability \& Management, 15(1), 85-94.

Mupeta, G. (2017). The Factors That Determine Internal Audit Effectiveness in the Selected Public Sector and Parastatal Organizations in Zambia. The International Journal of Multi-Disciplinary Research, 1-23.

Ofori, C \& L. Lu. (2018). The Evaluation of Internal Audit Functions for Effective Public Sector Administration. A Survey of Accra Metropolitan Assembly, Ghana. International Journal of Academic Research in Accounting, Finance and Management Sciences, 8(2), 19-27.

Omar, Sharofi, H. I. M., Mohd-Shahrir, H. R. (2007). Public sector accounting in Malaysia. Kuala Lumpur, Malaysia: Thompson Learning.

Ratnawati, V. (2020). Factors affecting tax auditors' performance: the moderating role of locus of control. Problems and Perspectives in Management, 18(2), 36-45.

Saputra, K., S. Winarningsih \& E. Puspitasari. (2020). The Effect of Top Management Support on The Effectiveness of Public Sector Internal Audit in Indonesia with Competence and Independence as Intervening Variables. Journal Management, Business, and Accounting, 19(3), 243-257.

Schyf, D. (2000). Obstacles in establishing and operating a public sector internal auditing function in a developing country: The South African experience. Meditari Accountancy Research, 8, 145-181.

Shamsuddin, A. (2014). Factors that determine the effectiveness of internal audit functions in the Malaysian public sectors. International Journal of Business, Economics and Law, 5(1), 9-17.

Sterck, M., \& Bouckaert, G. (2006). International audit trends in the public sector. The Internal Auditor, 63(4), 49-53.

Udeh, S \& Nwadialor, E. (2016). Evaluation of effectiveness of internal audit in the Nigerian Public sector. European Journal of Business, Economics and Accountancy, 4(3), 44-58.

Van Gansberghe, C. (2005). Internal auditing in the public sector: A consultative forum in Nairobi, Kenya, shores up best practices for government audit professionals in developing nations. Internal Auditor, 62(4), 69-73. 
(C) 2022 by the authors; licensee Growing Science, Canada. This is an open access article distributed under the terms and conditions of the Creative Commons Attribution (CC-BY) license (http://creativecommons.org/licenses/by/4.0/). 